NBER WORKING PAPER SERIES

WORLD WAR I AND THE RESTRUCTURING OF INTERNATIONAL BUSINESS

\author{
Ted Fertik \\ Naomi R. Lamoreaux \\ Working Paper 28224 \\ http://www.nber.org/papers/w28224 \\ NATIONAL BUREAU OF ECONOMIC RESEARCH \\ 1050 Massachusetts Avenue \\ Cambridge, MA 02138 \\ December 2020
}

This paper is forthcoming in French in La rupture? La Grande Guerre, l'Europe et le XXème siècle, eds. Pierre-Cyrille Hautcoeur, Florence Descamps, Patrick Fridenson, and Laure Quenouelle-Corre (Paris: Comité pour l'histoire économique et financière de la France, 2021). We are grateful to the volume editors for their comments and also to participants in the preparatory conference, “The Great War at the Century's Scale: Breaking Up, Parenthesis or New Cycle," held at French Ministry of Finance in Paris in 2018. The views expressed herein are those of the authors and do not necessarily reflect the views of the National Bureau of Economic Research.

NBER working papers are circulated for discussion and comment purposes. They have not been peer-reviewed or been subject to the review by the NBER Board of Directors that accompanies official NBER publications.

(C) 2020 by Ted Fertik and Naomi R. Lamoreaux. All rights reserved. Short sections of text, not to exceed two paragraphs, may be quoted without explicit permission provided that full credit, including $(\odot$ notice, is given to the source. 
World War I and the Restructuring of International Business

Ted Fertik and Naomi R. Lamoreaux

NBER Working Paper No. 28224

December 2020

JEL No. N10,N40,N60,O14

\begin{abstract}
$\underline{\text { ABSTRACT }}$
This paper considers the effect of the First World War on large-scale businesses in SecondIndustrial-Revolution industries like steel, electricity, and chemicals. For firms in the nations of the Entente, we argue, the war mainly interrupted long-term trends that resumed in the aftermath of the conflict. For Germany, however, the war and its subsequent territorial settlements had a disruptive impact on the economic geography of key industries. The global restructuring that resulted from the collapse of the Habsburg, Romanov, and Ottoman empires and Germany's loss of its colonial possessions set up a new kind of international rivalry as German firms sought to regain their dominance by contracting with emerging nations in the European periphery and the Global South to build industrial capacity, forcing Britain and the now capital-rich United States to compete for this business or see their influence in these areas decline. The end result of this rivalry was the construction of massive steel works in Brazil and other industrializing countries around the world. These investments would provide the foundation for the import-substituting policies of the post-World War II era.
\end{abstract}

Ted Fertik

Working Families Party

1 Park Lane

Mount Vernon, NY 10552

ted.fertik@gmail.com

Naomi R. Lamoreaux

Department of Economics

Yale University

27 Hillhouse Ave., Rm. 39

Box 208269

New Haven, CT 06520-8269

and NBER

naomi.lamoreaux@yale.edu 


\title{
World War I and the Restructuring of International Business
}

\author{
Edward S. Fertik and Naomi R. Lamoreaux
}

Beginning in the late nineteenth century and continuing through the first third or so of the twentieth century, the leading economies of Europe and North American underwent a technological transformation known as the Second Industrial Revolution. New science-based industries such as steel, chemicals, electricity, and automobiles took center stage, as First Industrial Revolution industries such as textiles and shoes passed into relative decline. Because the new industries were much more capital- and energy-intensive than those they surpassed, the Second Industrial Revolution required a transformation in the organization of enterprise. Small, economically specialized, owner-run enterprises gave way to large, horizontally and vertically integrated, managerially directed enterprises capable of exploiting economies of both scale and scope. $^{1}$

The First World War occurred in the midst of this process of transformation, and despite its cataclysmic effect on the economies of the main belligerents, the war was, for the most part, just an interruption. This was especially true for the Entente. Although Second Industrial Revolution industries had a major role to play in the war effort, these sectors had started to develop before the war (some were already quite mature), and they continued along essentially the same path afterwards. There were, of course, some special consequences for particular industries such as chemicals, where German firms had been in the lead and war authorities expropriated their intellectual property for the benefit of competitors. But otherwise for Entente countries the story was generally one of continuity rather than change. The situation was

\footnotetext{
${ }^{1}$ For an overview, see Alfred D. Chandler, Jr., Scale and Scope: The Dynamics of Industrial Capitalism (Cambridge, Mass.: Harvard University Press, 1990).
} 
different in Germany, however. There the war and its subsequent territorial settlements had a considerable impact on the economic geography of key industries like steel, which in turn affected the structure of business organization.

The war mattered as well for the spread of Second Industrial Revolution industries around the globe. Two developments were especially relevant. The first was the reordering of the international financial pecking order-the rise of the United States to the status of a creditor nation and the relative weakening of the economies and finances of the European belligerents, particularly Britain, whose currency had anchored the international gold standard throughout the long nineteenth century. The second was the global restructuring that resulted from the collapse of the Habsburg, Romanov, and Ottoman empires and Germany’s loss of its colonial possessions. This restructuring encouraged the development of nationalist movements in the European periphery and Global South, movements whose leaders demanded the economic accoutrements of modern nationhood, particularly investments in Second Industrial Revolution industries like steel. It also set up a new kind of international rivalry among the leading industrial powers to meet those demands. Germany was the main instigator of the competition as it sought to rebuild its international economic position. German steel firms began to contract with emerging nations to satisfy their demand for industrial capacity, forcing Britain and the now capital-rich United States to compete for this business or see their influence in these areas decline. The end result of this rivalry was the construction of massive steel works in Brazil and other industrializing countries around the world. These investments would provide the foundation for the import-substituting policies of the post-World War II era. 


\section{The Entente: Continuities in the Growth of Large-Scale Enterprises}

As Alfred D. Chandler, Jr. has shown, innovations like the railroad and telegraph, which increased the speed of transportation and communications, made it possible to concentrate production in large plants and thus to exploit technological changes that increased the efficient scale of production. These benefits were most pronounced in Second Industrial Revolution industries such as steel, chemicals, and automobiles where there were both significant technical economies of scale and advantages to concentrating production near sources of bulky raw materials. As Chandler has also shown, however, it was not sufficient for enterprises in these new industries simply to build large-capacity plants. Reaping economies of large-scale production depended on the ability to run these plants smoothly at high levels of capacity, which in turn required, first, a steady flow of raw material inputs so that production did not have to be slowed while awaiting supplies, and second, the capacity to ensure that sales kept pace with the volume of production to prevent costly accumulations of inventory. In many industries, maintaining the necessary flow of inputs and outputs required firms to integrate backward into raw materials or forward into distribution. However, the extent to which such integration was required depended on the thickness of existing supply and distribution networks, as well as on the characteristics of the product. Thus vertical integration was much less necessary in a compact country such as Britain than in the much larger and less densely populated United States. It was also more necessary in an industry like steel, where any delays in ore supplies forced blast furnaces to be shut down at enormous cost, or in industries such as sewing machines 
and reapers where sales depended on building consumers' confidence that these expensive purchases could be easily serviced if they broke down. ${ }^{2}$

Different countries were in different stages of this process of industrial reorganization on the eve of the First World War. Among the three main victorious Entente powers, the United States was furthest along, and so we focus our discussion on its experience in order to highlight the sources of the transformation. Although France was substantially behind Britain, the war had broadly similar effects on businesses in these two countries, and so we discuss their experiences together. In all three countries, Second Industrial Revolution industries were of major importance to the war effort, and as a result firms in these sectors grew larger and more profitable. The boost was only temporary, however, and in the war's aftermath firms had to find civilian uses for their expanded capacity. For the most part they returned to the development path they had been on before the fighting started.

The United States

At first glance it might seem as if the war marked a break in the development of largescale enterprises in the United States because big businesses were much more stable after the war than they had been before. Richard C. Edwards has tracked the performance of the 100 largest firms in the U.S. in 1903 and in 1919. Firms in the first group did relatively poorly; fully twothirds either lost ground in terms of the real value of their assets or had been liquidated by 1917. By contrast, the 100 largest firms in 1919 did remarkably well, with very few of them (less than

${ }^{2}$ Alfred D. Chandler, Jr., The Visible Hand: The Managerial Revolution in American Business (Cambridge, Mass.: Harvard University Press, 1977); Chandler, Scale and Scope; Oliver E. Williamson, "The Modern Corporation: Origins, Evolution, Attributes,” Journal of Economic Literature 19 (Dec. 1981): 1537-1568; George J. Stigler, “The Division of Labor is Limited by the Extent of the Market," Journal of Political Economy 59 (June 1951): 185-193; Leslie Hannah, "Logistics, Market Size, and Giant Plants in the Early Twentieth Century: A Global View,” Journal of Economic History 68 (March 2008): 46-79. 
10 percent) experiencing any similar decline, even a half century later. ${ }^{3}$ This stabilization had little or nothing to do with the war, however. To be successful in the oligopolistic industries of the Second Industrial Revolution, large firms had to learn to compete on dimensions other than price. They also had to learn how to navigate an increasingly hostile political environment. Big businesses had largely mastered these lessons by the time the U.S. entered the Great War in 1917, and they were able to reap the rewards of the resulting stability with the return of peace. As a result, over the next decade productivity growth in manufacturing was the highest in the twentieth century, and it was especially rapid in industries such as primary metals, chemicals, petroleum, and automobiles. ${ }^{4}$

During the last quarter of the nineteenth century firms in emerging Second Industrial Revolution industries had often found themselves enmeshed in destructive price wars as they competed to secure enough orders to run their plants at the capacity needed to capture economies of scale. To stem this competition they had experimented with a variety of collusive arrangements, starting with simple “gentlemen’s” agreements not to cut prices and progressing to highly structured pools and cartels. These arrangements were not initially illegal, but they were unenforceable at law, and as result rarely lasted for long. Out of desperation, firms responded to their inability to control price competition by merging; approximately 1,800 firms disappeared into nearly 160 horizontal combinations during the so-called Great Merger Movement of 18961904. ${ }^{5}$ Mergers were not in themselves a cure for competition, however. Unless the consolidations were able to erect barriers to entry (which most were not), whenever they tried to

\footnotetext{
${ }^{3}$ Richard C. Edwards, "States in Corporate Stability and the Risks of Corporate Failure," Journal of Economic History 35 (June 1975): 428-457.

${ }^{4}$ Alexander J. Field, A Great Leap Forward: 1930s Depression and U.S. Economic Growth (New Haven: Yale University Press, 2011), 52-53

${ }^{5}$ Naomi R. Lamoreaux, The Great Merger Movement in American Business, 1895-1904 (New York: Cambridge University Press, 1985).
} 
raise prices to recoup their profits, new firms would enter the market and the combines' market shares would drop. Shaw Livermore collected earnings data from 1901 to 1932 for 136 mergers that he deemed powerful enough at the time of their formation "to influence market conditions." He found that 37 percent of them were complete failures, while only 44 percent could be regarded as successes. ${ }^{6}$ Moreover, those that did not fail had to worry about antitrust prosecution. The mergers had provoked a political reaction that made illegal combinations in restraint of trade or that attempted to monopolize commerce. The Supreme Court broke up the Standard Oil, American Tobacco, and DuPont in 1911, and General Electric and the Aluminum Company of America shortly thereafter signed consent decrees with the Justice Department. In the wake of those victories, the government launched suits against a number of big companies, including U.S. Steel, International Harvester, and National Cash Register. ${ }^{7}$

The firms that survived this shakeout period learned to compete in the new institutional environment by means other than price cutting. They deployed advertising and other marketing strategies to build brand loyalty, improved their internal operations by integrating backward into raw-material production and forward into distribution, stayed on the technological cutting edge by investing in in-house $R \& D$, engaged in mergers for strategic advantage rather than horizontal combination, and more generally erected barriers to entry in any way they could without inviting antitrust prosecution. ${ }^{8}$ In the steel industry, for example, years of destructive price competition and failed pools led in the late 1890s to a series of mergers among finished goods producers, including American Steel and Wire, American Tin Plate, American Sheet Steel, National Tube,

${ }^{6}$ Shaw Livermore, “The Success of Industrial Mergers,” Quarterly Journal of Economics 50 (Nov. 1935): 68-96. See also Lamoreaux, Great Merger Movement, Ch. 5.

${ }^{7}$ Henry R Seager and Charles A. Gulick, Jr., Trust and Corporation Problems (New York: Harper \& Bros. 1929),

${ }^{8}$ Chandler, Visible Hand; Lamoreaux, Great Merger Movement, Ch. 5. 
and in 1901 to that great merger of mergers, the United States Steel Corporation, the first billiondollar corporation, which took in all of these earlier mergers plus Carnegie Steel and other major crude-steel manufacturers. Under the leadership of Judge Elbert H. Gary, U.S. Steel stabilized competition in the industry. Gary’s strategy was two-fold: to erect barriers to entry by buying up or negotiating long-term leases on the lion's share of the nation's iron ore reserves (largely accomplished by 1907); and to discourage price competition in the industry by a combination of example and moral suasion (the famous Gary dinners held after the Panic of 1907). These policies attracted the attention of antitrust authorities in the federal government, which filed suit against the company in 1911. The case dragged on for years, finally reaching the Supreme Court in 1917, whereupon it was delayed until after the war and finally, in 1920, resolved in favor of the corporation. The industry then continued during the 1920s on the oligopolistic path that Gary had laid out during the company’s first decade. Because the existing crude-steel producers (U.S. Steel, Bethlehem, Republic, and a few smaller enterprises) together controlled virtually all of the iron-ore reserves in the country, there was no threat of competition from new entrants. Sheltered by U.S. Steel's pricing umbrella, each of the firms concentrated on developing its own market niche. $^{9}$

Whereas the steel industry had largely completed its transition to a new oligopolistic structure by the outbreak of the First World War, automobiles was just beginning the process. The industry was still populated by a large number of relatively small firms, most of which produced cars by craft or group assembly methods, but a few firms were pulling ahead, increasing their share of the market. The most important of these was the Ford Motor Company.

${ }^{9}$ Lamoreaux, Great Merger Movement, Chs. 5-6; Seager and Gulick, Trust and Corporation Problems, Chs. 13-14; Gertrude G. Schroeder, The Growth of Major Steel Companies, 1900-1950 (Baltimore: Johns Hopkins Press, 1953); Chandler, Scale and Scope, 127-140. 
Henry Ford, the company's founder, believed that if he could build a low-priced, high-quality car, that would be both rugged and powerful, he could sell as many as he could turn out. He set about designing a car and, more importantly, figuring out how to manufacture it at a low cost using dedicated machine tools and assembly lines. By 1913 he had succeeded and almost immediately began to plan for the development of a huge vertically integrated manufacturing complex, buying the land for what would become the famous River Rouge facility in 1915. During the war, Ford manufactured boats there, but the war interrupted Ford's plans for the facility, and it was not until the early 1920s that the company seriously began to develop the site, building the world's largest car factory, an electrical generating plant, transportation facilities, and ultimately steel and glass factories. ${ }^{10}$ Nor were Ford's innovations copied by other companies as they geared up production for the war. The first company to adopt the new methods on a large-scale was General Motors (GM) beginning in 1923. Chrysler followed later in the decade. The new mass production methods made the "big three" dominant; together they accounted for about two-thirds of industry output in 1929. Most other companies continued to use group assembly methods, until they were killed off during the Great Depression. ${ }^{11}$

Another major innovation of the period—-the in-house research laboratory—followed a similar time path, first emerging before the war but spreading mostly afterwards. One of the first companies to create an in-house laboratory was the American Telephone and Telegraph (AT\&T). Its officers had long opposed investing in research and development (R\&D) because they believed that it was better to buy inventions on the market than to try to forecast the future

\footnotetext{
${ }^{10}$ David A. Hounshell, From the American System to Mass Production, 1800-1932: The Development of Manufacturing Technology in the United States (Baltimore: Johns Hopkins University Press, 1984): Chs. 6-7.

${ }^{11}$ Daniel M. G. Raff, "The Puzzling Profusion of Compensation Systems in the Interwar Automobile Industry," in Coordination and Information: Historical Perspectives on the Organization of Enterprise, eds. Naomi R. Lamoreaux and Daniel M. G. Raff (Chicago: University of Chicago Press, 1995), 13-29; Timothy F. Bresnahan and Daniel M. G. Raff, "Intra-Industry Heterogeneity and the Great Depression: The American Motor Vehicles Industry, 1929-1935,” Journal of Economic History 51 (June 1991): 317-331.
} 
direction of technological change. ${ }^{12}$ In 1907, however, a change in leadership brought a change in views. At about the same time, new breakthroughs in wireless communication (radio) posed challenges to the telephone's dominance in short-distance communication, forcing the company to double down on long-distance communication, which radio could not then deliver. Managers who supported the idea of in-house R\&D secured funding for a small laboratory to develop the necessary amplifier. The lab did not succeed in this effort-AT\&T had to buy the necessary patents from outside inventors — but the facility helped make the technology commercially practicable. Perhaps more important, the lab demonstrated its utility by securing numerous relatively minor patents that could be used defensively, bolstering the company's competitive position in a way that was consistent with the antitrust laws. Executives became convinced of the lab’s value and gradually expanded its budget. In 1925, the company founded Bell Labs, which over the next few decades would garner thousands of patents and seven Nobel Prizes. ${ }^{13}$

The history of the research laboratory founded by General Electric Company (GE), was similar. GE had been formed by merger in 1892, and it maintained its dominance for decades with the help of a formidable patent portfolio, entering into cross-licensing agreements with its only significant competitor in electrical lighting and power equipment, Westinghouse. GE created its first in-house industrial research laboratory in 1901 to develop an improved lamp technology that would replace Edison's original lighting patents, which had expired. Although the company eventually had to purchase patent rights for the technology it needed in Germany,

\footnotetext{
${ }^{12}$ Naomi R. Lamoreaux and Kenneth L. Sokoloff, "Inventors, Firms, and the Market for Technology in the Late Nineteenth and Early Twentieth Centuries," in Learning By Doing in Firms, Markets, and Countries, eds. Lamoreaux, Daniel M. G. Raff, and Peter Temin (Chicago: University of Chicago Press, 1999), 19-57.

${ }^{13}$ Leonard S. Reich, "Industrial Research and the Pursuit of Corporate Security: The Early Years of Bell Labs,” Business History Review 54 (Winter 1980): 502-529; and Reich, The Making of American Industrial Research (New York: Cambridge University Press, 1985), Ch. 7; Kenneth Lipartito, "Rethinking the Invention Factory: Bell Laboratories in Perspective," in The Challenge of Remaining Innovative: Insights from TwentiethCentury American Business, eds. Sally H. Clarke, Naomi R. Lamoreaux, and Steven W. Usselman (Stanford, CA: Stanford University Press, 2009), 132-159.
} 
the patents accumulated by the laboratory proved extraordinarily valuable in bargaining with rivals, and GE gradually expanded its investment in R\&D. These bargaining chips became all the more important in 1911, when an antitrust suit forced the company to abandon an effort to cartelize the electric lamp industry, and the company substantially expanded its commitment to the lab. ${ }^{14}$ Whether one looks at GE's expenditures on the lab or the number of research employees, the story is the same: steady expansion in the early twentieth century, especially after 1911; little growth during the First World War and its immediate aftermath, when GE research personnel were working on war projects elsewhere; and then a resumption of growth in the 1920 s that quickened in the latter part of the decade. ${ }^{15}$

Relatively few companies built in-house R\&D labs during the first decade of the twentieth century, but the numbers gradually accelerated over the next several decades. According to surveys conducted by the National Research Council, about 37 new industrial research labs were founded per year between 1909 and 1918. The number grew to 66 per year between 1919 and 1928 and to 74 per year from 1929 to 1936, and then dropped back to 39 per year over the next decade. Research employment in these labs increased by a factor of almost ten during the interwar period, rising from about 6,700 in 1921 to 19,500 in 1933 to 58,300 in 1940. ${ }^{16}$ Some scholars have attributed the growth of in-house R\&D during this period to the experience of the First World War, but neither the timing nor the incidence of the investments is

${ }^{14}$ Leonard S. Reich, "Lighting the Path to Profit: GE’s Control of the Electric Lamp Industry, 1892-1941,” Business History Review 66 (Summer 1992): 305-334; W. Bernard Carlson, "Innovation and the Modern Corporation: From Heroic Invention to Industrial Science," in Companion Encyclopedia of Science in the Twentieth Century, eds. John Krige and Dominque Pestre (London: Routledge, 2003), 203-226.

${ }^{15}$ George Wise, Willis R. Whitney, General Electric, and the Origins of U.S. Industrial Research (New York: Columbia University Press, 1985), 246-247; Reich, Making of American Industrial Research, Chs. 4-5.

${ }^{16}$ David C. Mowery and Nathan Rosenberg, Technology and the Pursuit of Economic Growth (New York: Cambridge University Press, 1989): 62-67. 
consistent with that explanation. ${ }^{17}$ The trends are more consistent with the reorganization of American business and the new patterns of oligopolistic competition that were developing by the second decade of the twentieth century, particularly the discovery that patents could be used to erect barriers to competition. ${ }^{18}$ In addition, during the stock-market boom of the late 1920 s, investors encouraged the development of in-house R\&D by rewarding companies that had amassed large portfolios of patents. ${ }^{19}$

The one exception to this generalization about timing is chemicals, an industry that was more directly affected by the war because German firms had been the main global suppliers of dyestuffs and other organic chemicals. The outbreak of fighting in Europe, and especially the tightening of the British blockade on German shipping early in 1915, led to serious shortages of these materials and stimulated investment in the industry. Du Pont, for example, began to build a dyestuffs factory in New Jersey in early 1917. These activities obtained a boost after the U.S. entered the war, and the federal government offered the new entrants tariff protection. In addition, empowered by the Trading with the Enemies Act, the government expropriated all U.S. patents that had been granted to German chemical firms and licensed them on a non-exclusive basis to American manufacturers. Although German companies returned to the U.S. market after the war and patented at even higher levels than before, the war seems to have allowed American firms to gain a foothold in the industry. After the war, patenting by U.S. firms increased in categories of chemicals where they had received licenses of German technology, and there was a

\footnotetext{
${ }^{17}$ Carlson, for example, asserts that World War I demonstrated the value of R\&D to managers but does not provide any evidence for this claim. See "Innovation and the Modern Corporation," 217.

${ }^{18}$ Mowery and Rosenberg, Technology and the Pursuit of Economic Growth, Ch. 4. In the late 1930s, antitrust authorities would move against this method of forestalling competition. See Naomi R. Lamoreaux, "The Problem of Bigness: From Standard Oil to Google,” Journal of Economic Perspectives 33 (Summer 2019), forthcoming.

${ }^{19}$ See Tom Nicholas, “Stock Market Swings and the Value of Innovation, 1908-1929,” in Financing Innovation in the United States, 1870 to the Present, eds. Naomi R. Lamoreaux and Kenneth L. Sokoloff (Cambridge, Mass.: MIT Press, 2007), 217-245.
} 
tremendous growth in investment in R\&D labs in the industry. ${ }^{20}$ Nonetheless, the story was not one of unqualified success. Du Pont struggled throughout the 1920s with its dyestuffs business and only achieved profitability with the help of more tariff protection and imported German scientists. $^{21}$ The company was much more successful with its diversification into paints. This investment was a product of the war only in the sense that Du Pont was searching for new uses for the plants it had built to produce smokeless powder for the military. Nonetheless, it was the need to learn to manage the investment in paints, not dyestuffs, that led the company to pioneer the development of the decentralized multi-divisional business structure (m-form). A few other companies went through a similar restructuring during the 1920s, but this innovation was not generally adopted by large-scale American businesses until the second half of the twentieth century. $^{22}$

One other important change that seemed to be associated with First World War was the rise of the United States to the top of the international financial pecking order and its shift from debtor to creditor status. Although this change was crystallized by the war, it was in fact the culmination of trends long in the works. The U.S. economy had been growing rapidly for decades in relative terms, and it was only a matter of time before it achieved creditor status. Indeed, the U.S. had surpassed Britain in total industrial output in the 1890s and in industrial output per capita around 1910. During the nineteenth century, the U.S. had been a major exporter of raw materials and agricultural products and a major importer of manufactured goods.

${ }^{20}$ L. F. Haber, The American Chemical Industry, 1900-1930: International Growth and Technological Change (Oxford: Oxford University Press, 1971), 185-188; Petra Moser and Alessandra Voena, "Compulsory Licensing: Evidence from the Trading with the Enemy Act," American Economic Review 102 (Feb. 2012): 296427; Mowery and Rosenberg, Technology and the Pursuit of Economic Growth, 62-67.

${ }^{21}$ David A. Hounshell and John Kenly Smith, Jr., Science and Corporate Strategy: Du Pont R\&D, 19021980 (New York: Cambridge University Press, 1988), Ch. 3.

${ }^{22}$ Alfred D. Chandler, Jr., Strategy and Structure: Chapters in the History of American Industrial Enterprise (Cambridge, Mass.: MIT Press, 1962). 
Beginning in the 1890s, however, the share of manufactured goods in total U.S. exports had begun to increase dramatically. The rise was especially significant in the more resourceintensive manufacturing industries of the Second Industrial Revolution, particularly automobiles and advanced machine technologies that used significant amounts of steel. It was a culmination of the business developments we have been discussing, as well as other extensive late-nineteenth investments in the discovery and extraction of mineral resources. ${ }^{23}$

The shift to the status of creditor nation did not result in a decline in foreign investment in the U.S. Although inflows of funds fell off during the war years, by the late 1920s foreign investment in the U.S. had more than regained its prewar level. What was different in the 1920s was the extent of U.S. investment abroad, which more than quadrupled between 1914 and 1929. ${ }^{24}$ Americans had been building manufacturing plants in Europe before the war and that trend continued afterwards, but capital flows to Europe increased as a result of the war. A major portion of the new American foreign investment was the staggering $\$ 10$ billion in direct U.S. government loans to the Entente Powers. ${ }^{25}$ U.S. businesses also significantly expanded their investments in other parts of the world, especially in Latin America, to build electrical infrastructure and advanced manufacturing capabilities. ${ }^{26}$ We will return to that important development below.

${ }^{23}$ Gavin Wright, "The Origins of American Industrial Success, 1879-1940,” American Economic Review 80 (Sept. 1990): 651-668; Douglas A. Irwin, “Explaining America's Surge in Manufacturing Exports, 1880-1913,” Review of Economics and Statistics 85 (May 2003): 364-376; and Irwin, Clashing over Commerce: A History of US Trade Policy (Chicago: University of Chicago Press, 2017), Chs. 6-7; Paul A. David and Gavin Wright, "Increasing Returns and the Genesis of American Resource Abundance," Industrial and Corporate Change 6 (Mar. 1997): 203245; Robert C. Allen, "International Competition in Iron and Steel, 1850-1913,” Journal of Economic History 39 (Dec. 1979): 911-937.

${ }^{24}$ Hugh Rockoff, “Until It's Over, Over There: The US Economy in World War I," in The Economics of World War I, eds. Stephen Broadberry and Mark Harrison (Cambridge, Eng.: Cambridge University Press, 2005), $\mathrm{xxx}-\mathrm{xxx}$.

${ }^{25}$ On the political significance of this massive and utterly novel form of international capital movement, Adam Tooze, The Deluge: The Great War, America and the Remaking of Global Order (New York: Penguin, 2014).

${ }^{26}$ Mira Wilkins, The Maturing of Multinational Enterprise: American Business Abroad from 1914 to 1970 (Cambridge, MA: Harvard University Press, 1974). 


\section{Britain and France}

Many business histories of Britain and France use the First World War as a break point in their narratives. If one examines the details of these accounts, however, the war most often appears as an interruption in underlying trends rather than a transformative event that altered the trajectory of business development. ${ }^{27}$ Certainly, the war was a major drain on the economies of these two countries that required a massive redirection of resources, and certainly, both countries suffered severe macroeconomic dislocations in the early 1920s. ${ }^{28}$ In terms of the development of large-scale enterprises, however, it is difficult to discern much of a break in trend. Britain was substantially ahead of France on the eve of the First World War, and it continued to widen its lead afterwards. Circa 1907-1912, Britain had 93 enterprises with capitalizations in excess of £2 million, whereas France only had 21. In 1929, Britain had 186 enterprises with capitalizations in excess of $£ 3$ million and France only had two. ${ }^{29}$

The development of large-scale enterprises in Britain followed a time path that was similar to that of the United States, but the rise was smaller in amplitude and did not generate a comparable political backlash. Much as in the U.S., vigorous price competition in the late nineteenth century had led to a wave of mergers and to significant instability in the ranks of large firms in the early twentieth century until executives mastered the new rules of oligopolistic competition. The share of the largest 100 firms in manufacturing output rose from 15 percent in

${ }^{27}$ A good example is Youssef Cassis, Big Business: The European Experience in the Twentieth Century (Oxford, Eng.: Oxford University Press, 1997). A quick search of the journal Business History turned up nearly 100 articles with 1914 as an end date in the title.

${ }^{28}$ See Stephen Broadberry and Mark Harrison, “The Economics of World War I: An Overview,” in Economics of World War I, eds. Broadberry and Harrison, 1-40; Pierre-Cyrille Hautcoeur, "Was the Great War a Watershed? The Economics of World War I in France," same volume,169-205; and Broadberry and Peter Howlett, “The United Kingdom during World War I: Business as Usual?” same volume, 206-234. See also Peter Temin, Lessons from the Great Depression (Cambridge, MA: MIT Press, 1989), Lecture 1.

${ }^{29}$ The 1907-12 figures are nominal capital, and the 1929 figures are paid-up capital. Cassis, Big Business, 10, 33. 
1907 to 17 percent in 1919 and then increased over the decade of the 1920s to 26 percent, only to drop again during the Great Depression and Second World War. The most significant growth came during the post-World War II period, when the share rose from 22 percent in 1948 to 40 percent in $1970 .^{30}$

In France, the growth of large-scale enterprises awaited to an even greater extent the post-World War II era. There was no wave of mergers at the turn of the century comparable to the ones that occurred in the U.S. and Britain, and the wave that occurred during the late 1920s was much smaller than in Britain (and also than in the U.S., despite the antitrust laws in effect there). The top 100 companies in France accounted for just 12 percent of industrial output in 1912, and they still accounted for only 16 percent in $1929 .{ }^{31}$ It would not be until the third quarter of the century that there was a major surge in the growth of large-scale business organizations. As Maurice Lévy-Leboyer wrote in 1980, “Today, for the first time, the corporate sector in France seems to conform to the general pattern of economic structure and hierarchical organization that is evident in other major industrial countries.”32

Such large-scale enterprises as there were in France were concentrated in heavy industries, though even there the largest firms were smaller in France than in Britain. Youssef Cassis notes, for example, that the British steel producer Stewarts \& Lloyds was in the bottom half of the top 100 British firms in 1930, but that it was larger than any of the large firms then

${ }^{30}$ Leslie Hannah, The Rise of the Corporate Economy (2nd edn.; London: Methuen, 1983), 180; Christopher J. Schmitz, The Growth of Big Business in the United States and Western Europe, 1850-1939 (Houndsmills, Eng.: Macmillan, 1993).

${ }^{31}$ Jean-Pierre Daviet, “An Impossible Merger? The French Chemical Industry in the 1920s,” in Management and Business in Britain and France: The Age of the Corporate Economy, eds. Youssef Cassis, François Crouzet, and Terry Gourvish (Oxford, Eng.: Oxford University Press, 1995), 171-190 at 171; Schmitz, Growth of Big Business, 47.

${ }^{32}$ Maurice Lévy-Leboyer, “The Large Corporation in France,” in Managerial Hierarchies: Comparative Perspectives on the Rise of the Modern Industrial Enterprise, eds. Alfred D. Chandler, Jr., and Herman Daems (Cambridge, Mass.: Harvard University Press, 1980), 117-160 at 117. See also Cassis, Big Business, Chs. 1-2. 
operating in France. ${ }^{33}$ In the early twentieth century, however, neither country was a world leader in steel, even though the key modern steel technology, the Bessemer process, had been originally developed in Britain. Britain was the top steel producer in the world in 1888 but already by the First World War produced less than half as much steel as Germany and less than one fourth as much as the U.S. Over the same period, moreover, its share of world steel exports declined from about three-quarters to under one quarter. ${ }^{34}$ The extensive debate over the sources of this relative decline need not concern us here. ${ }^{35}$ The key point is that the trend was already significantly underway before the war started and that it resumed in the war's aftermath. France produced only about a quarter as much steel as Germany on the eve of the First World War. Its relative position improved somewhat with the reacquisition of Alsace-Lorraine (France's output of steel surpassed Britain's by 1929 as a result), but there was no corresponding change in the scale of business organization. ${ }^{36}$

In terms of its share of global production, France's most successful industry in the early twentieth century was automobiles. It was the world's leading producer at the turn of the century and second only to the U.S. from 1904 to 1930 . The firms that would become France's three leading automobile manufacturers during the 1920s were already well established before the First World War. Citroën was still relatively small, but Peugeot and Renault were already in the

${ }^{33}$ Cassis, Big Business, 5.

${ }^{34}$ Peter Temin, “The Relative Decline of the British Steel Industry, 1880-1913,” in Henry Rosovsky, Industrialization in Two Systems: Essays in Honor of Alexander Gerschenkron (New York: John Wiley \& Sons, 1966), $140-155$ at 140.

35 The dominant view that emerged from this debate was that the decline was not a result of entrepreneurial or managerial failure but rather from the protectionist policies pursued by the U.S. and Germany and from the shift to new major deposits of iron ore that had newly been discovered or that had been made useable by technological advances. See Temin, "Relative Decline of the British Steel Industry”; Donald N. McCloskey, Economic Maturity and Entrepreneurial Decline: British Iron and Steel, 1870-1913 (Cambridge, Mass.: Harvard University Press, 1973); Bernard Elbaum, “The Steel Industry before World War I," in The Decline of the British Economy, eds. Elbaum and William Lazonick (Oxford, Eng.: Oxford University Press, 1986), 51-81. Steven Tolliday, however, argues in the same Elbaum and Lazonick volume that the resulting industry structure limited the possibilities for rationalization during the interwar period. See "Steel and Rationalization Policies, 1918-1950," 82-108.

${ }^{36}$ Cassis, Big Business, 16, 60-61. 
top ranks of the European automobile industry. British firms began gaining on French producers around 1909, and two (Morris and Austin) would emerge along with Ford, which opened a branch plant in England in 1909, to dominate the British segment of the industry during the interwar period. Before the war, however, none of the French or British firms operated on the scale of Ford-in 1913 Ford produced over 200,000 cars, as opposed to 5000 by the largest French manufacturer and 3000 by the largest British—and, though the leading companies in both countries benefited from war contracts, Ford's innovations in mass production would not diffuse in either France or Britain until the 1920s. ${ }^{37}$

In other Second Industrial Revolution industries, firms in Britain and France were more dependent on foreign technology. Electrical companies were formed in both countries in the late nineteenth century to exploit the lighting and power systems developed by American inventors Charles F. Brush, Thomas A. Edison, and Elihu Thomson. The Anglo-American Brush Electric Lighting Corporation was founded in 1880, for example, and Thomson-Houston Française in 1893. The latter was the only large firm in the French industry until the 1920s, but there were a number of important entrants in Britain, including companies tied to both American and German firms. ${ }^{38}$ One of them, the British Thomson-Houston Company (which was owned by GE after the 1892 merger in the United States) combined with a number of other important electrical companies in the late 1920s to form the giant Associated Electrical Industries. Its most important competitor (and the largest firm in the industry circa 1930) was the General Electric Company (no connection with the American GE), which had its origins in the 1880s but grew

${ }^{37}$ Roy Church, The Rise and Decline of the British Motor Industry (Houndmills, Eng.: Macmillan, 1994), Ch. 1; Roy Church and Michael Miller, "The Big Three: Competition, Management, and Marketing in the British Motor Industry, 1922-1939,” in Essays in British Business History, ed. Barry Supple (Oxford, Eng.: Oxford University Press, 1977), 163-186; Cassis, Big Business, 55-57; Patrick Fridenson, Histoire des Usines Renault (Paris: Seuil, 1972); James M. Laux, The European Automobile Industry (New York: Twayne, 1992).

${ }^{38}$ I. C. R. Byatt, The British Electrical Industry, 1875-1914: The Economic Returns to a New Technology (Oxford, Eng.: Oxford University Press, 1979) 
into one of 50 largest firms in Britain through a number of important mergers that occurred during the war and its immediate aftermath. The third most important firm in the industry in the interwar period, the English Electric Company, was also a product of wartime mergers, but it did not achieve much success until after it was reorganized in 1931. In general, however, the mergers seem to have pushed British firms into the top ranks of world producers, and by 1925 Britain had forged ahead of both the US and Germany in the export of electrical equipment. ${ }^{39}$ In France, Thomson-Houston Française dwarfed other French electric companies in the early part of the century but faced growing competition in the 1920s, especially from the Compagnie Générale d’Électricité, which grew during and after the war, again to a large extent by mergers. French firms did not, however, achieve the same level of global success as British, and most outward investment by French electrical companies was confined to territories within the French empire. $^{40}$

Although the mergers that transformed the electrical industry would probably have occurred in the absence of the war, the chemical industry was more directly affected by the conflagration, both because of the enormous demand for explosives and because of Germany's prewar dominance in important segments of the industry, particularly dyestuffs. The most significant long-run consequence of the war was the creation of new dye-making capacity in both countries as a result of government initiatives. The British government played a critical role in organizing and financing the transformation of an incumbent firm, Read Holliday, into British Dyes Ltd., and the French government similarly promoted the creation of Cie Nationale de

${ }^{39}$ Hannah, Rise of the Corporate Economy, 110-112; Robert Fitzgerald, "International Business and the Development of British Electrical Manufacturing, 1886-1929,” Business History Review 91 (Spring 2017), 31-70.

${ }^{40}$ Cassis, Big Business, 27-28, 58-59; William J. Hausman, Peter Hertner, and Mira Wilkins, Global Electrification: Multinational Enterprise and International Finance in the History of Light and Power, 1878-2007 (Cambridge, Eng.: Cambridge University Press, 2008), 160-161. 
Matières Colarantes (CNMC). Neither firm was particularly successful. The British government pushed in 1926 for British Dyes to merge with the country’s other major chemical firms, Nobel Industries and United Alkali, to form Imperial Chemical Industries (ICI). ICI was a large, managerially directed enterprise that quickly developed significant in-house research capabilities enabling it finally to succeed in dyestuffs and also to develop an extensive list of innovative products. In France, CNMC struggled until it was acquired in 1923 by Kuhlmann, the largest French company that was exclusively a chemical producer. Kuhlmann bought up other companies during the 1920s but does not seem to have rationalized its management of these concerns the way ICI did in Britain and certainly was not comparable in size. The other large chemical firms in France straddled various industries (St. Gobain was primarily a glass manufacturer and what became Péchiney made aluminum), and their trajectories were less affected by the war than Kuhlmann's. Rhône-Poulenc, which would become France’s most important chemical firm in the post-World War II period, was a later arrival, the product of the merger of two medium-sized companies in $1928 .{ }^{41}$ Thus even in chemicals, developments in the late 1920s played a key role in the industry's ultimate success in both Britain and France.

We do not wish to belittle the economic trauma of the war or of the return to peace and to the gold standard. The tangle of war debts and the problem of German reparations continued to afflict European industrial firms, who throughout the 1920s had to negotiate fluctuating exchange rates and ongoing capital shortages. British and French businesses would undoubtedly have done better under more favorable macroeconomic circumstances. Nonetheless, it should not be forgotten that many of them emerged from the war with profits of scandal-inducing magnitudes that they could use for new investments and that there were also significant infusions

\footnotetext{
${ }^{41}$ Haber, Chemical Industry, 189-195, 291-306; Chandler, Scale and Scope, 356-366; Cassis, Big Business, 27, 58-60.
} 
of American capital into Europe after the war. Moreover, some of the most important problems these enterprises faced, such as shrinking export markets for their goods, resulted from the longrun rise of the U.S. to the status of the major industrial power, a change that the war crystalized but did not cause. The relatively slow growth of large-scale enterprises was of a piece with prewar trends, and though the war was a major disruption to their business, it did not alter the basic trajectory of their development.

\section{The Transformation of German Industry}

As in the United States, the rise of big business in Germany was a story of the Second Industrial Revolution. Though German railroads were largely state-owned, in the key, tightly interconnected sectors of steel, chemicals, and electrical machinery, Imperial Germany was the only Second Industrial Revolution economy that generated corporate behemoths to match America’s giants. To Carnegie and Bethlehem Steel, Germany had Thyssen, Krupp and the Gutehoffnungshütte, each of which was vertically integrated from coal and ore mining all the way to machines and armored ships, and which made up for their smaller domestic market by becoming the world leaders in steel exports. To Dow and Du Pont, Germany had Bayer and BASF. And to GE and Westinghouse, Germany had AEG and Siemens. In terms of technological advance, Germany was widely considered the world leader in chemistry, and in electrical engineering Germany’s top firms had no inferiority complex. Lacking a mass market for standardized agricultural equipment, Germany had no machinery firms on the order of International Harvester, but its machinery sector as a whole was enormous, and dominated international markets in many product lines, from printing presses and diesel motors (M.A.N.), to 
cranes and mining equipment (DEMAG), to equipment for municipal water and gas utilities (BAMAG).

World War I led to far more dramatic shifts in business organization in Germany than in Britain, France, or the United States, for the simple reason that Germany was the only one of the industrial leaders to be on the losing side of the war. Territorial changes and the powerful admixture of nationalist resentment and financial weakness that led to Germany’s searing postwar episode of hyperinflation both contributed to major reorganizations of German big business. Germany’s Versailles-imposed territorial losses-especially the return of AlsaceLorraine to France and the splitting of Upper Silesia between Poland and Germany-upset the economic geography of Germany’s key heavy industrial regions. The Ruhr iron and steel firms had had their major iron ore properties in what was now French Lorraine, as well as many blast furnaces. The Saar was placed outside of the German customs area, and was to be put essentially at the disposal of French industry as part of the reparations program. ${ }^{42}$ The major plants of the Upper Silesian coal and steel industry were now in Poland, facing vexing trade regulations and enormous political pressures from a Polish state which—quite sensibly, and, in fact, correctlyfeared that German-owned companies would be a locus of irrendentist machinations. ${ }^{43}$ These territorial shifts called forth major industrial reorganizations, in particular a marked shift among the Ruhr steel producers away from Lorraine ores to Swedish ones. (Ironically, this gave a productivity boost to the German industry, since the Swedish ores contained roughly twice as high a concentration of iron as the French ones. Once German blast furnace practice adapted to

${ }^{42}$ On the wrenching postwar changes to the German iron and steel industry, Gerald D. Feldman, Iron and Steel in the German Inflation, 1916-1923 (Princeton, NJ: Princeton University Press, 1977).

43 Alfred Reckendrees, "Business as a Means of Foreign Policy or Politics as a Means of Production? The German Government and the Creation of Friedrich Flick’s Upper Silesian Industrial Empire (1921-1935),” Enterprise and Society 14, no. 1 (March 2013), 99-143. 
its new material inputs, it easily made up in increased efficiency for what it lost in brute capacity. ${ }^{44}$ ) What had formerly been a zone of extensive firm-level integration across national borders became a site of industrial and geopolitical conflict. ${ }^{45}$

The hyperinflation, which eviscerated the savings of middle class Germans, was in many ways a boon to large-scale German industry. With the so-called "flight to real values," big German firms found themselves quite suddenly able to engage in a spectacular consolidation spree of "concern-building." Some large firms bought others outright, as with the purchase by the Haniel-family-owned Gutehoffnungshütte coal, iron, steel and machinery combine of the Bavarian M.A.N. machinery giant. ${ }^{46}$ Others, most famously the coal and steel baron Hugo Stinnes, formed Interessengemeinschaften (“communities of interest”) with Siemens in a somewhat abortive attempt to find economies of scope. ${ }^{47}$ Other combines were formed by industrialists who were little more than profiteers, most infamously Friedrich Flick, who scooped up coal and steel properties in central Germany and - secretly - in Polish Upper Silesia. ${ }^{48}$

With the stabilization of the German currency and German public finances after the U.S.engineered Dawes Plan of 1924, German industry had to quickly adjust from an easy money regime to a very hard one. Already before 1924 major German firms had begun to borrow from American banks, but in small amounts and without much fanfare. After the Dawes loan, the

\footnotetext{
${ }^{44}$ W. O. Blanchard, "The Iron and Steel Industry of Europe,” Journal of Geography 27, no. 7 (Oct. 1928): 253-54. Hermann Wenzel, "Zur Frage der Eisenerzversorgung Deutschlands, insbesondere Rheinland-Westfalens"," in Die Rohstoffversorgung der deutschen eisenerzeugenden Industrie. Verhandlungen und Berichte des Unterausschusses für Gewerbe: Industrie, Handel und Handwerk (III. Unterausschuß), by Ausschuss zur Untersuchung ... (Berlin: E. S. Mittler \& Sohn, 1928), 58.

${ }^{45}$ On the pre-war pattern of cross-border investment, see especially Carl Strikwerda, "The Troubled Origins of European Economic Integration: International Iron and Steel and Labor Migration in the Era of World War I,” The American Historical Review 98, no. 4 (October 1993): 1106-29.

${ }^{46}$ Christian Marx, Paul Reusch und die Gutehoffnungshütte: Leitung eines deutsch Großunternehmens (Göttingen: Wallstein Verlag, 2013).

${ }^{47}$ Gerald Feldman, The Great Disorder: Politics, Economics and Society in the German Inflation, 19141924 (New York: Oxford University Press, 1993).

${ }^{48}$ Kim Christian Priemel, Flick: eine Konzerngeschichte vom Kaiserreich bis zur Bundesrepublik (Göttingen: Wallstein Verlag, 2013).
} 
marquee names of German industry increasingly turned to America for the funding necessary to "rationalize” German industry in line with the demands of international competitiveness—where Germany labored under the dual burden of a hard gold currency while France and especially Britain were still floating-and reparations, which effectively were a tax on German exports. ${ }^{49}$ The rationalization wave of horizontal mergers was motivated by a desire to both imitate and compete with America. ${ }^{50}$ American money was used not just for financial legerdemain but for massive investment in cutting edge integrated plant. Out of it came the Vereinigte Stahlwerke AG (Vestag), Europe's second-largest corporation and the second-largest steel producer in the world after U.S. Steel, and IG Farbenindustrie, Europe’s largest corporation and the single largest chemical manufacturer on the planet. ${ }^{51}$ These firms were dominant enough to be able to largely dictate the structure of export markets in their respective fields, such as through the International Steel Cartel, whose policies corresponded in many respects to the requirements of the Vestag's throughput. ${ }^{52}$

The war also affected German international business through the damage it did to the German banking system. The war and the post-war inflation essentially eliminated the international asset position of the German banking system. Themselves dependent on foreign borrowing, German banks had minimal ability to finance the exports of German industry. The weakness of the German banking system combined with Germany’s urgent need to increase exports in order to maintain employment and to comply with the Dawes Plan pushed German

${ }^{49}$ William C. McNeil, American Money and the Weimar Republic: Economics and Politics on the Eve of the Great Depression (New York: Columbia University Press, 1986).

${ }^{50}$ Alfred Reckendrees, "Die Vereinigte Stahlwerke A. G. 1926-1933 und 'das glänzende Beispiel Amerika,”’ Zeitschrift für Unternehmensgeschichte 41, no. 2 (Jan. 1996): 159-86.

${ }^{51}$ Alfred Reckendrees, Das "Stahltrust”-Projekt: Die Gründung der Vereinigte Stahlwerke A.G. und ihre Unternehmensentwicklung 1926-1933/34 (München: C.H.Beck, 2000). On the formation of IG Farben, Peter Hayes, Industry and Ideology: IG Farben in the Nazi Era (Cambridge: Cambridge University Press, 1987).

52 See, for example, Stephen A. Schuker, The End of French Predominance in Europe: The Financial Crisis of 1924 and the Adoption of the Dawes Plan (Chapel Hill: University of North Carolina Press, 1976), 373. 
banks and German heavy industry to come together to lobby the German government for credit facilities, especially to resume the historic role of German heavy industry as a supplier for Russian industrialization. ${ }^{53}$ Other European countries also developed various forms of publicprivate partnerships to provide export credit insurance or guarantees, mostly as a way to support exporters through conditions of significant exchange risk in overseas sales. The British, for example, introduced an export credit guarantee program in 1921, and by the time an American government researcher studied the question in 1934, almost every European country had developed some form of this basic instrument. ${ }^{54}$ But in most countries, and especially in Britain, France, and - finally, in 1934 - the U.S., officials strenuously worked to assure bondholders that export credit insurance in no way represented the extension of government-backed long-term capital to foreigners, since this would undermine foreign sovereigns' incentive to pay existing debts. ${ }^{55}$ The elimination of almost all of Germany's overseas claims as a result of the war meant that German suppliers were less entangled with questions of foreign debt and concessions, and the relative weight of specialized machinery and equipment in German exports as opposed to textiles meant that German industry had less to fear from nascent import substitution than Britain’s in particular. By 1926, once most of the disruption wrought by the war had been stabilized, German industry was more concentrated, more geared to exports, and more sophisticated in its modes of enlisting state support than any of its major rivals. ${ }^{56}$

${ }^{53}$ Gerald D. Feldman, “Die Deutsche Bank vom Ersten Weltkrieg bis zur Weltwirtschaftskrise 1914-1933,” in Die Deutsche Bank, 1870-1995, by Lothar Gall et al. (München: C. H. Beck, 1995), 249-58.

${ }^{54}$ Stella K. Margold, Export Credit Insurance in Europe Today (Washington, DC: GPO, 1934)

${ }^{55}$ Michael R. Adamson, “'Must We Overlook All Impairment of Our Interests?' Debating the Foreign Aid Role of the Export-Import Bank, 1934-41,” Diplomatic History 29, no. 4 (Sep. 2005): 589-623.

${ }^{56}$ See the summary of the iron and steel industry's strategy in Feldman, Iron and Steel in the German Inflation, 451-6. 


\section{New Nationalist Ambitions}

German international business confronted a new world whose needs it was in some ways ideally suited to serve. The territorial clauses of the peace treaties vanquished the Hohenzollern, Habsburg, Romanov and Ottoman Empires, leaving in their wake the new or rump states of Yugoslavia, Austria, Hungary, Czechoslovakia, Poland, Latvia, Lithuania, Estonia, and Turkey, and substantially redrawing the borders of already independent Bulgaria (for the worse) and Romania (for the better), not to mention the Soviet Union, which expropriated practically all private business and called into question whether Russia - the great emerging market of the pre1914 period—would ever again be an open field for international business. ${ }^{57}$ Germany’s overseas empire as well as most of the former Ottoman Empire were placed under the League of Nations "mandate” system, with the ostensible purpose of shepherding them towards independent nationhood. In colonies, protectorates, and independent but weak states across the world, nationalist stirrings transformed the political calculus of elites. Across the board, nationality was, for the first time in world history, declared the foundational principle of international legal ordering and the international state system, and nationalism - the conviction that the fate of a people was indissolubly tied to the fortunes of an autonomous, territorial statebecame a paramount force in international life. ${ }^{58}$

${ }^{57}$ Robert Gerwarth, The Vanquished: Why the First World War Failed to End (New York: Farrar, Straus and Giroux, 2016). Hassan Malik, Bankers and Bolsheviks: International Finance and the Russian Revolution (Princeton, NJ: Princeton University Press, 2018).

${ }^{58}$ Erez Manela, The Wilsonian Moment: Self-Determination and the International Origins of Anticolonial Nationalism (Oxford ; New York: Oxford University Press, 2009). Embrace of self-determination, however, in no way implied sovereign equality. See Susan Pedersen, The Guardians: The League ofNations and the Crisis ofEmpire (New York: Oxford University Press, 2015); Maja Spanu, "The Idea of Self-Determination: Hierarchy and Order after Empire” Unpublished dissertation, European University Institute, 2015; and Manu Goswami, "Rethinking the Modular Nation Form: Toward a Sociohistorical Conception of Nationalism," Comparative Studies in Society and History 44, no. 4 (Oct. 2002): 770-99. 
In this brave new world, national governments, both new and old, faced immense pressure to ensure political autonomy through economic means. ${ }^{59}$ This took myriad forms, depending on the nature of different countries’ past integration into the circuits of international capitalism, ranging from nationalization of foreign-owned firms, to renegotiation of concessions and sovereign debt, to tariffs and other forms of protection for domestic industries. Some of the new demands emanated directly from developing countries’ experience of the war, particularly the interruptions to global shipping that transmitted an acute inflationary shock from the Global North to the Global South. ${ }^{60}$ What all of the demands had in common were efforts to drive what were felt to be better bargains vis-à-vis foreign capitalists and firms. ${ }^{61}$ But what scholars have generally overlooked is that nationalism also called forth a need for foreign assistance in building out Second Industrial Revolution industries, especially steel, which loomed large in the industrialization programs of numerous old and new states. Industries like electricity also required foreign assistance, but these investments were relatively unproblematic from the point of view of business interests in the most powerful states: electricity is a non-competing good; and foreigners earned healthy profits selling generators and contracting to build out electricity grids. Steel promised profits from construction and kit, but also a hit to the export markets of national steelmakers.

${ }^{59}$ The following paragraphs draw heavily from Edward Fertik, "Steel and Sovereignty: The United States, Nationalism, and the Transformation of World Order, 1898-1941,” Unpublished dissertation, Yale University, 2018, especially chapters 2,3 , and 6 .

${ }^{60}$ See Adam Tooze and Ted Fertik, "The World Economy and the Great War," Geschicte und Gesellschaft 40, no. 2 (Jun. 2014), 214-238.

${ }^{61}$ For a survey, Henryk Szlajfer, Economic Nationalism and Globalization: Lessons from Latin America and Central Europe (Leiden: Brill, 2013). The experience of the former Habsburg lands is comprehensively covered in Alice Teichova, "East-central and south-east Europe, 1919-39," in The Cambridge Economic History of Europe Volume VIII, The Industrial Economies: The Development of Economic and Social Policies (Cambridge: Cambridge University Press, 1989), 887-982. 
This international situation set up potential conflicts of interest within the national political economies of the leading World War I belligerents. In particular, states that wished to industrialize were often indebted and sometimes in default to bondholders in Britain, France, and America, which made any provision of medium-term credit for industrialization programs problematic; and import substitution would likely come at the expense of exports from these same countries. At the same time in Britain and Germany in particular, builders of heavy machinery were politically potent. Their high-value added goods generated healthy export earnings in the immediate term, and, due to the path dependent quality of initial investments in a particular technology in industries like steel, over the longer term as well. It was common to hear manufacturers and government officials warn that a failure to establish a foothold in a newly industrializing market could leave a country’s heavy machinery makers permanently shut out. Their not-yet-Taylorized plants employed large numbers of skilled workers with high levels of shop floor power. Encouragement and even a measure of subsidization of these exports was, comparatively, a low-cost method of keeping down economically and politically troublesome unemployment.

In the 1920s, these conflicts were muted, as the governments of new states mostly complied with the rules of the pre-1914 regime of sovereign borrowing, wagering their industrialization programs on the easy availability of long-term capital via the New York—and, by 1926, London and Paris-capital markets. Capital for electrification of major cities and railroads in developing countries, for example, flowed out in massive quantities, either through funds raised by developing country governments, or through concessions to Belgian, French, British, Canadian and American firms. These projects often had a genuinely multinational quality to them. For example the largest corporation in Brazil in the 1920s was the Canadian- 
owned Brazilian Traction, which was the monopoly electricity provider in Rio de Janeiro and São Paulo. The firm, however, had bondholders throughout Europe and raised much of its capital in the 1920s in New York through the investment bank Dillon Read. ${ }^{62}$

The Depression, however, threw conflicts of interest into stark relief. ${ }^{63}$ The "mother of all sudden stops” brought on history’s largest wave of sovereign defaults, including-fatefully_ Germany itself. ${ }^{64}$ The governments of the countries in which bondholders were concentratedFrance, Britain, and America above all—faced substantial political pressure to prioritize bondholders’ demands, but also faced pressure to boost employment through support for exports. Germany, where the unemployment situation was severe, but the bondholders' lobby essentially non-existent, had a freer hand.

As early as 1930, conservative German governments looked to exploit Germany’s economic plight and the alarming rise of the far right to win concessions from the reparations creditors, who were also their enemies in World War I. ${ }^{65}$ Chancellor Heinrich Brüning's June 1931 threat to default on Germany’s reparations debt triggered a run on the Reichsmark and a complete collapse of the German banking system, ushering in the most acute phase of the Great Depression and the beginnings of a regime of exchange controls that would soon sweep across large swathes of the globe where balance of payments crises threatened massive economic

${ }^{62}$ Duncan McDowall, The Light: Brazilian Traction, Light, and Power Company Limited, 1899-1945 (Toronto: University of Toronto Press, 1988).

${ }^{63}$ Noel Maurer has explained the U.S.'s refusal to deploy the Marines in defense of bondholders' interests in the 1930s - in marked contrast to earlier decades - as a result of conflicts of interest between bondholders and direct foreign investors, for example sugar growers in Cuba. Maurer, The Empire Trap: the rise and fall of U.S. intervention to protect American property overseas, 1893-2013 (Princeton, NJ: Princeton University Press, 2013). Here we are referring to conflicts of interest between foreign investors generally and manufacturers of heavy equipment.

${ }^{64}$ Olivier Accominotti and Barry Eichengreen, "The mother of all sudden stops: capital flows and reversals in Europe, 1919-32,” Economic History Review 69 no. 2 (May, 2016), 469-492.

${ }^{65}$ Peter Krüger, Die Aussenpolitik der Republik von Weimar (Darmstadt: Wissenschaftlicher Buchgesellschaft, 1985). 
dislocation. ${ }^{66}$ Even as Germany won reprieve thanks to Herbert Hoover’s unilateral reparations moratorium, its leaders began a gradual but marked shift away from cooperation with the other major capitalist powers. ${ }^{67}$ Germany began a search for new markets and new sources of raw materials, and with increasing sophistication, used its exchange controls regime to pioneer new forms of bilateral trade and credit arrangements. In 1934, when Hjalmar Schacht imposed the socalled “New Plan,” all of Germany’s foreign trade became instrumentalized towards Hitler and Göring's superordinate priority of rearmament and war-readiness. The objective of Schacht's New Plan was to find the imports necessary to keep German rearmament moving without exploding the German balance of payments. ${ }^{68}$ As a logical consequence of successive German governments' decisions to default on the country’s international debts, Germany began a process of selective disengagement from economic relations with especially the U.S. and the British Empire, who were its largest trading partners, in favor of relations with the poorer but independent countries of Southeast Europe, the Middle East, Latin America, and East Asia. ${ }^{69}$ This economic-cum-diplomatic demarche has long been considered a prelude to Hitler’s expansionist and genocidal wars of conquest. In fact it was largely concentrated on parts of the world which German strategists had no illusions of being able to conquer and consisted of far more carrots than sticks. ${ }^{70}$ The carrot was access to German markets at above world-market

\footnotetext{
66 That the German financial crisis was caused by the actions of Germany's political leaders, and not through the leapfrogging of the Vienna Creditanstalt collapse in May 1931, is powerfully demonstrated in Thomas Ferguson and Peter Temin, "Made in Germany: The German Currency Crisis of July 1931," Research in Economic History 21 (2003), 1-53.

${ }^{67}$ On the Hoover Moratorium, see Robert W. D. Boyce, The Great Interwar Crisis and the Collapse of Globalization (Houndmills, Basingstoke, Hampshire: Palgrave Macmillan, 2009), 305.

${ }^{68}$ Adam Tooze, The Wages of Destruction: The Making and Breaking of the Nazi Economy (New York: Penguin, 2006).

${ }^{69}$ Albrecht O. Ritschl, "Nazi Economic Imperialism and the Exploitation of the Small: Evidence from Germany’s Secret Foreign Exchange Balances, 1938-1940,” The Economic History Review 54, no. 2 (May 2001): 324-45.

${ }^{70}$ Alan S. Milward, “The Reichsmark Bloc and the International Economy,” in The Führer State, Myth and Reality: Studies on the Structure and Politics of the Third Reich, ed. Gerhard Hirschfeld and Lothar Kettenacker (Stuttgart: Klett-Cotta, 1981), 377-413; Adam Tooze and Martin Ivanov, "Disciplining the 'Black Sheep of the
} 
prices, and-what scholars have completely overlooked-access to high-value capital goods, frequently on credit terms that represented a complete circumvention of effective credit boycotts in France, Britain and the U.S. In other words, German heavy industry and the German government forged an alliance of convenience with nationalist governments which, under the conditions of the Depression and growing international tensions, sought industrialization as a way to fortify national sovereignty.

Germany’s new export offensive saw German firms building railways, ports, factories, power plants, and steel mills in many parts of the world. Some of these were alarming enoughon commercial and strategic grounds - to businessmen and government officials in rival countries to bring about a reversal of past policy. In Kemal’s Turkey, for example, within two years of the signing of a 1933 clearing agreement, fully half of the Republic of Turkey’s foreign trade was being done with Germany. Jamming up so much of its foreign trade in blocked currencies allowed Turkey to plead foreign exchange poverty to the holders of the old Ottoman Debt — a financial albatross inherited from a state that no longer existed — resulting in dramatic reductions in debt payments. British engineering firms were furious that all of the best Turkish business was going to German firms. British cotton textile firms were furious that Turkish import substitution was destroying one of the “imperialism of free trade’s” great markets (thanks to the infamous “Capitulations,” Ottoman Turkey had effectively no tariff sovereignty). British diplomats feared that Germany’s economic and financial accommodations to Turkey were inclining its statesmen towards a pro-German orientation in their foreign policy. With the prospect of a £2 (later £3) million integrated iron and steel works dangled before them, British officials overruled the bondholders’ and textile manufacturers’ lobbies and the Bank of England

Balkans’: Financial Supervision and Sovereignty in Bulgaria, 1902-38,” Economic History Review 64, no. 1 (Feb. 2011): 30-51. 
in favor of machinery builders and friendly relations with an increasingly autonomous, nationalist government in Ankara. Not only that, the British government guaranteed the entirety of the sum, secured only by the surplus earnings of a minerals monopoly that the Turkish state owned and which amounted to nothing more, as British officials acknowledged, than "a promise to pay.” Schacht himself traveled to Turkey in November 1936 to try to prevent the contract from going to Britain, only to find that the Turks were fully satisfied with their negotiations and with their success in using growing German economic penetration as a wedge to pry loose concessions from Britain. The contract furthermore solidified Turkey’s preferred position of strict neutrality in the impending global great power conflict. In this way a combination of economic and strategic rationales brought about a pronounced shift in business-government relations in Britain. ${ }^{71}$

Something similar happened in Brazil. The nationalist government of Getulio Vargas had spent the first years of the Depression attempting to make small shifts towards a more developmentalist model of economic governance, while remaining broadly within the rules and norms of the old, export and sovereign debt-based regime. Starting in the mid-1930s, barter trade with Germany, in which Brazil largely exchanged a booming cotton crop for investment goods, and favorable deals with British heavy equipment manufacturers for projects like railway electrification, led to the U.S. government hearing a growing chorus of complaints from American capital goods producers. Before 1938, the U.S. government interpreted these complaints exclusively through the lens of export promotion. But in November 1937 Vargas declared himself dictator, in a coup that elevated the power of the top brass of the Brazilian military, where fascist sympathizers were a vocal minority. In April 1938 Brazil’s fascist party

\footnotetext{
71 This episode is recounted in detail in Fertik, “Steel and Sovereignty,” chapter 3.
} 
itself attempted a coup. With the alarming events in Europe of that year, American policymakers increasingly feared that a fascist fifth column in Brazil, buoyed by the perceived advantages of German-Brazilian barter trade, could make Brazil the beachhead for a German military assault on the western hemisphere. Already in 1938, Vargas was giving speeches indicating that the “solution” of “our national steel problem” would be a crucial consideration in Brazil’s foreign relations. By 1939, all three of the major German builders of steel mill equipment were vying for the contract to build a Brazilian national steel industry. Vargas, preferring - for geopolitical reasons - an American solution, tried to interest U.S. Steel. Despite the enthusiasm of the corporation’s engineers, J. P. Morgan \& Co. senior partner Thomas Lamont vetoed it in early 1940, on the grounds that a country in default to its bondholders was not a safe place in which to sink substantial investment capital. With Brazilian diplomats openly threatening that a failure by the U.S. to act would drive Brazil in to German arms, the U.S. government, through the ExportImport Bank, agreed in September 1940 to finance the entire project, at 4 percent interest over 10 years, with essentially no security for the loan. U.S. equipment would be purchased, but other than that, the American state would finance the keystone of Brazil's industrialization drive, over the objections of bondholders, steel exporters, and protectionist politicians. ${ }^{72}$

\section{Epilogue}

It was only after the Second World War that businesses in Europe were transformed along the lines of the American model, with U.S.-guaranteed military security, Marshall Plan funds, the first steps towards European integration, and mass migration from the countryside to the cities combining finally to overcome European doubts about mass production and mass

\footnotetext{
72 This sequence is covered in Fertik, "Steel and Sovereignty,” Chapters 5 and 6.
} 
markets. How much one can attribute this post-1945 transformation to the First World War is partly a question of definition. If one views the disruptions of the middle third of the twentieth century as a consequence of the First World War — that as, as the workings out of a Thirty-Years War touched off in 1914 — then in a certain deep sense World War I was ultimately the catalyst for the Americanization of European big business. But if one limits the war's duration to the conflagration of 1914-1918 proper, then it is hard to see it as having a transformative effect on Second Industrial Revolution businesses.

That was not the case for the spread of these businesses to developing countries. Here the direct economic experience of the First World War, as well as the wider nationalist explosion to which it gave rise, occasioned a worldwide restructuring of economic relations between advanced and developing countries, and industrialization emerged as a leading aspiration from South America to Eastern Europe to China. These changes created opportunities for some firms in the core Second Industrial Revolution countries, but challenges for others, and set up potential conflicts of interest between exporters and bondholders. Though muted in the 1920s, these conflicts became acute after the global wave of sovereign defaults set off by the Great Depression. Germany, where the machinery industry was dominant and overseas financial claims smallest, had the freest hand in developing means of government-industry cooperation to facilitate industrialization in places like Brazil, Turkey and China. The alarming success of German policy, which took on an increasingly geostrategic cast as Hitler’s expansionist ambitions became clearer, forced Britain and the U.S. to compete with similar initiatives of their own. The result was, in effect, a global credit regime for facilitating, on a bilateral basis, importsubstituting industrialization in developing countries - well before the mid-twentieth century, when the beginning of the era of "international development” is usually dated. Although the 
diffusion of Second Industrial Revolution technologies beyond their homelands in northwest Europe and the U.S. had to happen at some point, World War I both accelerated the process and altered the terms on which it was done, giving the new emerging nations more power to shape their own development than would probably otherwise have been the case. 